\title{
Nonlinear Models in Corporate Finance Research: Review, Critique, and Extensions
}

\author{
SHENG-SYAN CHEN* \\ Department of Finance, College of Management, Yuan Ze University, 135 Yuan-Tung Road, Chung-Li, Taoyuan, \\ Taiwan, Tel.: 886-3-4638800 ext. 667, Fax: 886-3-4354624 \\ E-mail: fnschen@saturn.yzu.edu.tw \\ KIM WAI HO \\ Division of Banking and Finance, Nanyang Business School, Nanyang Technological University, Nanyang Avenue, \\ Singapore 639798, Tel.: 65-67905740, Fax: 65-67937440 \\ E-mail: akwho@ntu.edu.sg \\ CHENG-FEW LEE \\ Department of Finance and Economics, School of Business, Rutgers University, Piscataway, New Jersey 08854- \\ 8054, USA, and Graduate Institute of Finance, National Chiao Tung University, Taiwan, Tel.: 732-4453907, \\ Fax: $732-4455927$ \\ E-mail:lee@rbs.rutgers.edu

\section{KESHAB SHRESTHA} \\ Division of Banking and Finance, Nanyang Business School, Nanyang Technological University, Nanyang Avenue, \\ Singapore 639798, Tel.: 65-67905738, Fax: 65-67913697 \\ E-mail: akeshab@ntu.edu.sg
}

\begin{abstract}
Since the work of Morck, Shleifer and Vishny (1988), nonlinear model specification has gained more attention in corporate finance research. In this paper, we provide a detailed review of the previous studies that have examined nonlinear relations in corporate finance. We review the theory and evidence in these studies and discuss the advantages and disadvantages of the various methodologies used to detect nonlinearity. We also suggest two possible methodological extensions, which we apply in the empirical analysis of $R \& D$ investment and firm value.
\end{abstract}

Key words: nonlinear models, residual analysis, nonlinearity with interaction effect

JEL Classification: C21, C31, G32

\section{Introduction}

Since the work of Morck, Shleifer and Vishny (MSV) (1988), nonlinear specification in regression models has gained more attention in corporate finance research. Morck, Shleifer and Vishny (1988) first use a piecewise linear regression model to examine nonlinear relationship between board ownership and firm value. Many researchers have since used the methodology to examine other issues. ${ }^{1}$ Wruck (1989) extends the piecewise regression methodology to examine nonlinear relationship between first differences in variables

${ }^{*}$ Corresponding author. 
(between abnormal returns and changes in ownership concentration). Thomas (1995), Martin (1996) and others adapt the MSV methodology to logistic regressions.

Other studies such as McConnell and Servaes (1990), Slovin and Sushka (1993) and Daines (2001) use a quadratic functional form to examine nonlinear relationships. Fields and Mais (1994) regress the slope of a function (the ratio of abnormal return to change in management ownership) against the independent variable (the level of management ownership). Finally, Allen and Cebenoyan (1991) and Pantzalis, Kim and Kim (1998) apply switching regressions to investigate nonlinear relations in corporate finance.

In the MSV piecewise regression model the number and locations of turning points are pre-determined. Generally, two turning points are assumed in most studies although Morck, Shleifer and Vishny (1988) have also examined models with more than two turning points. Morck, Shleifer and Vishny (1988) use the sum of squared errors as a criterion to determine the optimal combination of turning points. In most subsequent ownership studies, researchers use the same turning points as in Morck, Shleifer and Vishny (1988) (i.e., 5 and 25\%) without further model specification tests, even in cases where the variables in question are different from those used in Morck, Shleifer and Vishny (1988). ${ }^{2}$ As Morck, Shleifer and Vishny (1988) pointed out, the theoretical justification for the turning points is not strong. The ground for using the same 5 and $25 \%$ turning points for different variables without specification tests is even weaker.

The MSV piecewise regression model assumes that the turning points are pre-determined and sharp and that the relationship is linear between two adjacent turning points. In contrast, the quadratic and higher order polynomial regression models are smooth functions and allow the turning points to be determined endogenously. In switching regression models, break points are also determined endogenously and different relationships between the switching variables and the dependent variables are allowed across different regimes.

In view of the prevalence of nonlinear relationships reported in corporate finance literature, it is important to study the relative merits of various nonlinear models. This paper provides a detailed review of the methodologies used in extant corporate finance research to detect nonlinearity. We also discuss their advantages and disadvantages. Finally, we provide two possible extensions in methodology and present empirical analysis using these extensions.

The following section discusses the theoretical and empirical work reviewed in this article. Section 3 describes and compares the existing models. The possible problems associated with each model are also discussed. Section 4 proposes extensions in methodology and Section 5 presents the empirical analysis using these extensions. Section 6 provides some concluding remarks.

\section{Nonlinear relationships in corporate finance research}

This section reviews existing corporate finance literature in which nonlinear relationships are examined. The list of papers discussed here is not intended to be exhaustive. Our aim is to show that nonlinear relations are common in corporate finance research. For ease of discussion, we classify the studies according to the research areas. 


\subsection{Firm value (or firm performance) and ownership structure}

Many of the corporate finance studies that report nonlinear models are related to ownership structure research. Existing theories suggest that managerial ownership and other ownership variables may have a positive or negative impact on firm value (or performance). The interaction of these effects may give rise to a nonlinear relationship between ownership variables and other variables such as firm value or firm performance. According to Jensen and Meckling's (1976) alignment-of-interests hypothesis, higher managerial ownership would result in lower agency costs and higher firm value. Leland and Pyle's (1977) signaling model also suggests a positive relation between management ownership and firm value. However, Demsetz (1983) and Fama and Jensen (1983) suggest that when a manager owns a sufficiently large stake, negative entrenchment effects may become significant. Stulz (1988) also suggests that the relation between managerial ownership and firm value is positive up to a certain ownership level and becomes negative as management ownership increases further. He argues that the premium a hostile bidder must pay increases with management ownership, but the probability of a successful takeover decreases as management ownership increases.

Morck, Shleifer and Vishny (1988) empirically test the relationship between board ownership and firm value, as proxied by Tobin's Q, using a piecewise linear regression model. They find a significantly positive relation between board ownership and Q in the 0 to $5 \%$ board ownership range, a significantly negative relation in the 5 to $25 \%$ range, and a weak relation beyond $25 \%$. The authors argue that the entrenchment effects dominate the alignment-of-interests effects in the 5 to $25 \%$ range. Holderness, Kroszner and Sheehan (1999) obtain similar results for their 1935 sample. $^{3}$

McConnell and Servaes (1990) provide empirical evidence supporting Stulz's (1988) prediction. They find a curvilinear relation between insider ownership and Tobin's Q, with turning point for insider ownership at around 49\% in the 1976 sample and 38\% in the 1986 sample. ${ }^{4}$ When the sum of insider ownership and large blockholding is used as the ownership measure, the turning point is about $43 \%$ in the 1976 sample and $40 \%$ in the 1986 sample. Anderson and Reeb (2003) report a similar quadratic relation between founding-family ownership and firm performance. The inflection point ranges from 27.6 to $31.0 \%$, depending on the measure of firm performance used. Thus, these studies suggest that the location of the turning point is sensitive to the definitions of the ownership and firm performance variables, the inclusion of other variables in the model, and the period of study.

Anderson and Lee (1997) shows that ownership data provided by different databases can affect the empirical results in prior studies. ${ }^{5}$ They examine the MSV piecewise linear model, McConnell and Servaes' (1990) quadratic model, and Bagnani et al. (1994) piecewise linear regression relating management ownership to the firm's unsystematic risk. However, in their analysis, they do not include any control variables.

Nonlinear relation between managerial ownership and firm performance is also observed in international studies. For example, Short and Keasey (1999) report a cubic relation between firm performance and managerial ownership for a sample of UK firms, with the turning points at 15.6 and $41.8 \%$ managerial ownership. The study shows that institutional factors can influence the location of the point of managerial entrenchment. For a sample of 
Korean firms before the economic crisis in 1997, Joh (2003) also finds a nonlinear relation between ownership concentration and firm performance using both the piecewise linear regression model and the cubic polynomial specification.

Studies such as Cho (1998) and Himmelberg, Hubbard and Palia (1999) suggest that managerial ownership is endogenously determined. Using a simultaneous equation framework, Cho (1998) shows that managerial ownership, specified in piecewise linear form, has no significant impact on firm value. Using panel data, Himmelberg, Hubbard and Palia (1999) also cannot conclude that changes in managerial ownership affect firm performance. They examine both the quadratic and the piecewise linear specifications for the ownership variable.

The studies reviewed so far use cross-sectional analysis to examine the nonlinear relation between firm value and managerial ownership. The impact of managerial ownership on firm value has also been extensively researched in event studies. For example, Slovin and Sushka (1993) examine that the relation between the share price response to the death of an inside blockholder and the deceased's shareholding. By partitioning their sample into five ownership subsamples, they show that the abnormal return is significantly positive when the deceased's shareholding exceeds $10 \%$ of the firm's shares, beyond which, the larger the deceased's shareholding the more favorable the stock-market response. The positive effect is of smaller magnitude after $40 \%$ ownership is reached. In cross-sectional regressions, they find a significant quadratic relation between the abnormal return and the deceased's shareholding. In the subsequent sections, we will discuss several other studies that make use of the event study methodology to show the impact of ownership structure on firm value.

\subsection{Equity issues}

Adapting the MSV piecewise linear regression methodology, Wruck (1989) finds that when the level of ownership concentration after a private equity sale is low $(<5 \%)$ or high $(\geq 25 \%)$, the relation between abnormal return (change in firm value) and change in ownership concentration is positive. In the range of 5 to $25 \%$ ownership concentration, this relation is negative. The author suggests that the results are consistent with those of Morck, Shleifer and Vishny (1988). In contrast, Hertzel and Smith (1993) do not find similar relationship in their sample of private placements.

Fields and Mais (1994) examine the relation between management ownership and abnormal return at the announcement of a seasoned equity issue. They show that the ratio of abnormal return to change in management ownership is negatively related to the level of management ownership. They argue that since the ratio of abnormal return to change in management ownership measures the slope of the firm value function, their results are consistent with the prediction of Stulz (1988). In contrast, Brous and Kini (1994) find that abnormal returns associated with seasoned equity issues are not significantly related to insider ownership and insider ownership squared.

Slovin, Sushka and Lai (2000) find a significant curvilinear relation between excess returns and ownership concentration for placings in the UK, with a maximum point at about $40 \%$ ownership concentration. They argue that placings by firms with concentrated 
ownership enhance value by increasing ownership dispersion. The study finds that ownership concentration does not affect excess returns at insured rights offerings in the UK.

Mikkelson, Partch and Shah (1997) examine ownership and operating performance of firms that go public. They find that operating performance both within one year of the offering and during the first ten years of public trading is unrelated to the change in insider ownership surrounding the IPO, the insider ownership following the offering, and the square of the insider ownership following the offering. They explain that despite the declines in insider ownership following an IPO, managerial incentives are not materially affected, given the substantial level of insider holdings immediately after the offering. The authors further suggest that the lack of association between operating performance and insider ownership years after going public may be explained by new pressures on managers of a publicly traded firm.

Aggarwal, Krigman and Womack (2002) suggest that substantial underpricing at IPO generates information momentum, which shifts the demand curve for the firm's stock outwards. They show that higher ownership by managers is positively correlated with underpricing, underpricing is positively correlated with research coverage, and research coverage is positively correlated with stock returns and insider selling at lockup expiration. Using a quadratic specification for underpricing, they find a concave relation between underpricing and research coverage.

\subsection{Corporate payout policy}

Rozeff (1982) suggests that cash dividend payment forces the firm to the capital market more frequently, thus reducing agency costs as a result of the increased market scrutiny. He proposes that insider ownership and dividend policy are substitute tools used to reduce agency costs. This implies a negative relation between insider ownership and dividend payout. Schooley and Barney (1994) argue that beyond a point of managerial entrenchment, an increase in managerial ownership increases agency costs, and hence, higher dividend payout may be necessary to increase market scrutiny on the firm. They find a curvilinear relation between dividend yield and CEO stock ownership, with a minimum point at $15 \%$ stock ownership.

Lie (2000) suggests that special dividends and self-tender offers can reduce agency problems associated with excess cash, especially in firms with poor investment opportunities. The evidence shows that abnormal returns associated with these events are significantly positively related to the cash level prior to the event $(C A S H)$ and the interaction variable between low-Tobin's Q firms and CASH (Low $Q \times C A S H)$. The study further examines whether the relation between the announcement return and the interaction variable (Low $Q \times C A S H$ ) is stronger for firms with poor control mechanisms, which are proxied by four dummies (insider holdings $<5 \%$, insider holdings $>25 \%$, outsiders on board $<50 \%$, and no outside blockholders). The results show that the three-way interaction terms between Low-Q, CASH, and each of the four dummies are not significant.

Alangar, Bathala and Rao (1999) suggest that the information content of dividend-change announcements, as proxied by the absolute value of the announcement return, is related to 
the degree of pre-announcement information asymmetry, which is proxied by institutional ownership. They argue that the relation may be nonlinear because beyond some level of institutional ownership, further increases in institutional ownership may not result in additional reduction in information asymmetry. The study finds significantly negative coefficients for the two dummy variables that indicate the intermediate and high institutional ownership groups, the omitted set being the group with the lowest institutional ownership. ${ }^{6}$ The evidence suggests a positive relation between the information content of dividendchange announcements and the degree of pre-announcement information asymmetry in the stock. $^{7}$

\subsection{Corporate debt}

Nonlinear relations are also common in corporate capital structure research. For example, Diamond (1991) predicts a nonmonotonic relation between bond rating and debt maturity. Diamond argues that firms with highest credit ratings issue short-term debt because of lower refinancing risk. Firms with lower credit ratings would prefer longer-term debt to minimize refinancing risk. However, firms with very poor credit ratings are unable to borrow longterm because of adverse selection problems. Barclay and Smith (1995) and Stohs and Mauer (1996) provide empirical support for this prediction, though their model specifications are somewhat different. Barclay and Smith (1995) define two variables: (1) a bond rating dummy that equals one if the firm has a Standard and Poor's (S\&P) bond rating and zero otherwise; and (2) a bond rating variable for rated firms that equals one if the firm's S\&P bond rating is AAA, through 27 if the rating is $\mathrm{CCC}$ or below. They find that both the bond rating variable and the bond rating dummy are positively related to debt maturity, suggesting that nonrated firms have more short-term debt, and among the rated firms, lower-rated firms issue more long-term debt than do higher-rated firms. Stohs and Mauer (1996) construct a bond rating variable, where $\mathrm{AAA}=1, \ldots, \mathrm{CCC}=7$, and unrated firms receive a code of 8 . Using a quadratic specification for the bond rating variable as well as dummy variables that split the bond rating range into three parts, they find an inverted U-shaped relation between bond rating and debt maturity.

Bagnani et al. (1994) investigate the relation between the pricing of risky debt and management ownership. They argue that when managerial ownership is low, an increase in managerial ownership increases management's incentives to increase stockholder wealth at the expense of bondholder wealth (e.g., higher risk taking). This is expected to lead to higher risk of outstanding debt and higher bond return premia. At larger management ownership levels, management becomes more risk averse and the positive relation between bond returns and management ownership may become weaker or, beyond a certain level, even switch. The study reports a significantly positive relation between management ownership and bond return premia in the 5 to $25 \%$ ownership range and a weak evidence for a nonpositive relation when ownership exceeds $25 \%$.

Anderson, Mansi and Reeb (2003) find a piecewise linear relation between founding family ownership and the cost of debt, with one breakpoint at $12 \%$ ownership stake. Family firms with less than $12 \%$ ownership stakes enjoy about a 42.9 basis point lower cost of debt financing than non-family firms. For high family ownership firms, the study shows 
an incremental increase in debt costs of 21.1 basis points, suggesting that large family holdings might lead to wealth expropriation from bondholders or that families entrench themselves at the expense of other claimants. Using a quadratic specification, the study finds evidence of a similar curvilinear relation between family ownership and the cost of debt financing.

Event risk covenants (ERC) in debt issues could reduce shareholder-bondholder conflicts (Bae, Klein and Padmaraj, 1994) or entrench managers (Cook and Easterwood, 1994). Roth and McDonald (1999) find that the announcement return associated with a debt issue is positively related to management ownership in the $0-5 \%$ range and negatively related to the interaction variable between management ownership in the $0-5 \%$ range and a PUT dummy that equals one if the debt issue includes a poison put and zero otherwise. The other two ownership segments (5-25 and $>25 \%)$ and the interaction between these segments and the PUT dummy are not significant. This suggests that as management ownership increases through a low range of ownership $(<5 \%)$, shareholders respond more favorably to debt announcements, but they suffer from the use of poison puts. The authors argue that their results support the entrenchment view of ERCs.

\subsection{Corporate cash holdings}

Opler et al. (1999) examine the agency explanations for corporate cash holdings, in addition to other possible determinants. They suggest that if holding cash is costly and managerial ownership helps align management and shareholders' interests, then cash holdings are expected to fall with management ownership. However, managerial ownership may also protect management against market discipline. To the extent that managerial ownership makes management more risk averse, one would expect cash holdings to increase with managerial ownership. Using piecewise regression model with break points of 5 and $25 \%$ insider ownership, the authors find that management ownership has a positive effect on cash holdings for low ownership $(<5 \%)$, but the relation is not significant for the intermediate and high ownership ranges. Their results are consistent with managerial risk aversion.

\subsection{Corporate investment decisions}

Allen and Cebenoyan (1991) apply a switching regression model to examine bank acquisitions and ownership structure. The switching variables are insider shareholdings, $\alpha$, and shareholder concentration, $\gamma$. They find positive bidder returns only for firms with high levels of both $\alpha$ and $\gamma$. They find a significant entrenchment effect for high $\alpha$, low $\gamma$ firms. Using a quadratic specification, Subrahmanyam, Rangan and Rosenstein (1997) find that bidder returns in bank acquisitions are associated only with high levels of insider ownership. Loderer and Martin (1997) apply a simultaneous equation methodology and find no relation, linear or nonlinear, between executive ownership and bidder returns or between executive ownership and the acquiring firm's Tobin's Q.

In an OLS regression model, Cho (1998) finds that the relation between investment (capital expenditure or research and development expenditure) and insider ownership is 
positive for ownership levels below $7 \%$, negative for levels between 7 and $38 \%$, and positive for levels above $38 \%$. However, there is no evidence of nonlinearity in a simultaneous equation framework. In addition, the results show that investment affects corporate value which, in turn, affects ownership structure. This is in contrast to the earlier works by Morck, Shleifer and Vishny (1988) and others that suggest that ownership structure affects corporate value.

Denis, Denis and Sarin (1997a) show that the level of diversification is negatively related to managerial ownership and outside blockholdings. Using a quadratic term for managerial ownership, they find some evidence of nonlinearity in the relation between the level of diversification and managerial ownership. They find little evidence that the value loss from diversification is related to either managerial or outside blockholder ownership.

Thomas (1995) investigates the nonlinear effects of ownership structure on the hiring of advisors in merger and acquisition transactions. They use the same 5 and $25 \%$ turning points for each of the three separate ownership measures (institutional ownership, insider ownership, and 5\% blockholdings) in a single logistic regression. The study finds that institutional ownership increases the propensity of firms to hire M\&A advisors. The effect is nonlinear in institutional ownership.

Martin (1996) and Ghosh and Ruland (1998) examine the method of payment in corporate acquisitions. Using break points of 5 and $25 \%$ managerial ownership in a logistic piecewise linear regression model, Martin (1996) shows that the acquirer's management ownership is not related to the probability of stock financing over small and large ranges of ownership, but is negatively related over a middle range. The results suggest that over an intermediate range of acquirer's managerial ownership, managers may be concerned about their control of the firm, and hence, increases in ownership lead to a lower likelihood of stock financing. Ghosh and Ruland (1998) argue that target's managers with low ownership in their firm are less likely to obtain significant influence in the combined firm even if stock financing is used. However, when their ownership exceeds certain level, there is a greater potential for them to exert significant influence in the combined firm as a major shareholder, and hence, the incidence of stock financing is expected to be higher as their ownership increases. The authors examine two segments of target's managerial ownership with a single break point of $3 \%$ and find evidence supporting their prediction.

Nonlinear relation is also reported in antitakeover provisions research. McWilliams (1990) shows that antitakeover rules benefit shareholders of firms with low managerial ownership $(<10 \%)$ by providing management with additional bargaining power, whereas for firms with high managerial ownership, antitakeover rules can harm shareholders by entrenching management. Boyle, Carter and Stover (1998) suggest that insiders can obtain protection from hostile takeover bids either directly via antitakeover provisions or indirectly via higher ownership. They examine the simultaneous determination of insider ownership and takeover protection using data from mutual savings and loans associations converting to stock form. They find that insider ownership is negatively related to the number of extraordinary antitakeover provisions at low levels of insider ownership $(<10.3 \%)$, but the relation is not significant at higher levels of insider ownership. 


\subsection{Board structure and activity}

Byrd and Hickman (1992) find a curvilinear relationship between bidding firms' abnormal returns and the proportion of independent outside directors on the board. The relation is positive over most of the range, but is significantly negative when independent outside directors hold a very high proportion of board seats, which implies that having too many independent outside directors may have a negative impact on firm value.

Denis, Denis and Sarin (1997b) show that the probability of top executive turnover is significantly less sensitive to performance when officers and directors own between 5 and $25 \%$ of the firm's shares than when they own less than $5 \%$. The results suggest that managers become entrenched at higher ownership levels.

Rosenstein and Wyatt (1997) study the stock-market reaction to announcements of inside managers being appointed to corporate boards. They find that the abnormal return is significantly negative when inside directors own less than $5 \%$ of the firm's common stock, significantly positive when their ownership is between 5 and $25 \%$, and insignificantly different from zero when ownership exceeds $25 \%$. The authors argue that at low levels of insider ownership, the addition of an inside director is likely to be an attempt to entrench existing management. At moderate levels of insider ownership, where managerial interests are more closely aligned with those of the outside shareholders, the benefits of having an inside manager's specialized knowledge outweigh the costs of managerial entrenchment.

Yermack (1996) finds that firm value (proxied by Tobin's Q) is negatively related to log of board size, which is consistent with the notion that board effectiveness suffers when the number of directors increases. The log form of the board size implies a convex relation, which the study confirms by using piecewise linear models and regressions against board size and board size squared.

Vafeas (1999) investigates the relation between board meeting frequency and firm performance. While there is a significantly negative relation between firm value and $\log$ of board meeting frequency in an OLS regression, the relation becomes insignificant in two-stage least squares (2SLS) regression in which log of board meeting frequency is endogenous. In both the OLS and 2SLS regressions, the study finds a quadratic relation between firm value and insider ownership.

\subsection{Risk-taking behavior of financial institutions}

Several studies have examined ownership structure and risk-taking behavior of financial institutions. An example is the paper by Cebenoyan, Cooperman and Register (1995). For 1988 , which is a period of regulatory leniency on savings and loans (S\&L) closures, the authors find a quadratic relation between insolvency risk and managerial ownership, with a turning point at around 25\% managerial ownership. At low managerial ownership levels, as managerial ownership rises, S\&Ls exhibited lower insolvency risk, suggesting that managers act to protect their undiversifiable unemployment risk. At higher managerial ownership, managers appear to have engaged in greater risk-taking behavior. In contrast, for 1991, which is a period of regulatory stringency, the study finds a significant linear relation between insolvency risk and managerial ownership, suggesting greater risk-reducing 
behavior for S\&Ls with a larger managerial ownership. This study shows that the functional form of the relation may depend on the regulatory environment.

\section{Model specifications in existing studies}

In this section, we summarize the empirical models used to estimate nonlinear relations. The notations used are as follows: $y_{i}$ is the dependent variable; $z_{i}$ is the independent variable that is hypothesized to have a nonlinear relation with the dependent variable; and $x_{i 1}, \ldots, x_{i k}$ are the $k$ control variables. Table 1 provides a list of examples of papers that have used the various models.

\subsection{The MSV piecewise regression model}

The MSV piecewise regression model can be generalized as follows: ${ }^{8}$

$$
y_{i}=\alpha_{1}+\beta_{1} x_{i 1}+\cdots+\beta_{k} x_{i k}+\theta_{1} z_{i 1}+\cdots+\theta_{p} z_{i p}+\varepsilon_{i}, i=1, \ldots, n
$$

where the piecewise variables, $z_{i 1}, \ldots, z_{i p}$, are defined as follows:

$$
\begin{aligned}
& z_{i 1}= \begin{cases}z_{i}, & \text { if } z_{i}<P_{1} \\
P_{1}, & \text { otherwise }\end{cases} \\
& z_{i j}= \begin{cases}0, & \text { if } z_{i}<P_{j-1} \\
z_{i}-P_{j-1}, & \text { if } P_{j-1} \leq z_{i}<P_{j}, \quad j=2, \ldots, p-1 \\
P_{j}-P_{j-1}, & \text { if } P_{j} \leq z_{i}\end{cases} \\
& z_{i p}= \begin{cases}0, & \text { if } z_{i}<P_{p-1} \\
z_{i}-P_{p-1}, & \text { otherwise }\end{cases}
\end{aligned}
$$

The piecewise linear relation is assumed to have $p-1$ break points, $P_{1}, P_{2}, \ldots, P_{p-1}$.

In order to apply the MSV methodology, the number and positions of the turning points have to be pre-determined. Apart from Morck, Shleifer and Vishny (1988), in which a model with seven break points is reported as one of the specification tests, most other studies assume two turning points. Further, while Morck, Shleifer and Vishny (1988) and Wruck (1989) report results on turning points other than the 5 and $25 \%$ ownership level, most subsequent ownership papers assume the same turning points of 5 and $25 \%$ without further specification checks. The 5 and $25 \%$ break points have more or less become 'standard' in ownership research even though the definitions of ownership variables in various studies may differ. For example, Morck, Shleifer and Vishny (1988) use percentage ownership of members of the board of directors. Wruck (1989) and Hertzel and Smith (1993) define their ownership variable as the share ownership of managers, directors, and 5\% or greater beneficial owners. McConnell and Servaes (1990), Hudson, Jahera and Lloyd (1992) and Bagnani et al. (1994) use insider ownership. Martin (1996) includes stock options in the 
Table 1. Nonlinear models in corporate finance research

\begin{tabular}{|c|c|c|c|}
\hline \multirow[b]{2}{*}{ Model } & \multirow{2}{*}{$\begin{array}{l}\text { Equation no. } \\
\text { in this paper }\end{array}$} & \multicolumn{2}{|c|}{ Examples of studies that use the model } \\
\hline & & Research area & References \\
\hline \multirow[t]{5}{*}{$\begin{array}{l}\text { Morck, Shleifer and Vishny } \\
\text { (1988) (MSV) Piecewise } \\
\text { regression model (including } \\
\text { logistic regression with } \\
\text { piecewise linear variables) }\end{array}$} & \multirow[t]{5}{*}{ (1) } & $\begin{array}{l}\text { Firm value (or firm } \\
\text { performance) and } \\
\text { ownership structure }\end{array}$ & $\begin{array}{l}\text { Morck, Shleifer and Vishny } \\
\text { (1988), Hudson, Jahera and } \\
\text { Llyod (1992), Anderson and } \\
\text { Lee (1997), Holderness, } \\
\text { Kroszner and Joh (2003). }\end{array}$ \\
\hline & & Corporate debt & $\begin{array}{l}\text { Bagnani et al. (1994), Anderson, } \\
\text { Mansi and Reeb (2003). }\end{array}$ \\
\hline & & Corporate cash holdings & Opler et al. (1999). \\
\hline & & $\begin{array}{l}\text { Corporate investment } \\
\text { decisions }\end{array}$ & $\begin{array}{l}\text { Thomas (1995), Martin (1996), } \\
\text { Cho (1998), Ghosh and } \\
\text { Ruland (1998). }\end{array}$ \\
\hline & & $\begin{array}{l}\text { Board structure and } \\
\text { activity }\end{array}$ & $\begin{array}{l}\text { Byrd and Hickman (1992), } \\
\text { Yermack (1996). }{ }^{\mathrm{a}}\end{array}$ \\
\hline $\begin{array}{l}\text { Wruck's (1989) adaptation } \\
\text { of MSV piecewise } \\
\text { regression model }\end{array}$ & (2) & Equity issues & $\begin{array}{l}\text { Wruck (1989), Hertzel } \\
\text { and Smith (1993). }\end{array}$ \\
\hline \multirow[t]{3}{*}{ Model with slope dummies } & \multirow[t]{3}{*}{ (3) } & Corporate payout policy & $\begin{array}{l}\text { Alangar, Bathala and Rao } \\
\text { (1999), Lie (2000). }\end{array}$ \\
\hline & & Corporate debt & $\begin{array}{l}\text { Barclay and Smith (1995), } \\
\text { Stohs and Mauer (1996), } \\
\text { Roth and McDonald (1999). }\end{array}$ \\
\hline & & $\begin{array}{l}\text { Board structure } \\
\text { and activity }\end{array}$ & $\begin{array}{l}\text { Denis, Denis and Sarin (1997b), } \\
\text { Rosenstein and Wyatt (1997). }\end{array}$ \\
\hline \multirow[t]{7}{*}{ Quadratic model } & \multirow[t]{7}{*}{ (4) } & $\begin{array}{l}\text { Firm value (or firm } \\
\text { performance) and } \\
\text { ownership structure }\end{array}$ & $\begin{array}{l}\text { McConnell and Servaes (1990), Slovin } \\
\text { and Sushka (1993), Anderson and Lee } \\
\text { (1997), Daines (2001), Anderson } \\
\text { and Reeb (2003), Woidtke (2003). }\end{array}$ \\
\hline & & Equity issues & $\begin{array}{l}\text { Brous and Kini (1994), Mikkelson, } \\
\text { Partch and Shah (1997), } \\
\text { Slovin, Sushka and Lai (2000), } \\
\text { Aggarwal, Krigman and } \\
\text { Womack (2002). }\end{array}$ \\
\hline & & Corporate payout policy & Schooley and Barney (1994). \\
\hline & & Corporate debt & $\begin{array}{l}\text { Stohs and Mauer (1996), Anderson, } \\
\text { Mansi and Reeb (2003). }\end{array}$ \\
\hline & & Corporate investment decisions & $\begin{array}{l}\text { Denis, Denis and Sarin (1997a), } \\
\text { Subrahmanyam, Rangan and } \\
\text { Rosenstein (1997). }\end{array}$ \\
\hline & & Board structure and activity & Yermack $(1996){ }^{\mathrm{a}}$ \\
\hline & & $\begin{array}{l}\text { Risk-taking behavior of } \\
\text { financial institutions }\end{array}$ & $\begin{array}{l}\text { Cebenoyan, Cooperman and } \\
\text { Register (1995). }\end{array}$ \\
\hline Cubic polynomial model & $\begin{array}{l}\text { Extension } \\
\text { of (4) }\end{array}$ & $\begin{array}{l}\text { Firm value (or firm performance) } \\
\text { and ownership structure }\end{array}$ & Short and Keasey (1999), Joh (2003). \\
\hline Fields and Mais' (1994) model & (5) & Equity issues & Fields and Mais (1994). \\
\hline Switching regression model & (6) & Corporate investment decisions & Allen and Cebenoyan (1991). \\
\hline $\begin{array}{l}\text { Simultaneous equation model } \\
\text { (with nonlinear specification) }\end{array}$ & (7) and (8) & $\begin{array}{l}\text { Firm value (or firm performance) } \\
\text { and ownership structure } \\
\text { Corporate investment decisions }\end{array}$ & $\begin{array}{l}\text { Cho (1998), Himmelberg, Hubbard } \\
\text { and Palia (1999). } \\
\text { Loderer and Martin (1997), Boyle, Carter } \\
\text { and Stover (1998), Cho (1998). }\end{array}$ \\
\hline
\end{tabular}

a Yermack (1996) uses piecewise linear and quadratic models as robustness checks on his log-linear model relating board size to firm value. 
Table 2. Cross-sectional regression of research and development expenditure: estimation of Eq. (20)

\begin{tabular}{lcrr}
\hline Independent variables & Coefficient & $T$-ratio & $P$-value (\%) \\
\hline Constant & 0.0081 & 0.963 & 33.6 \\
EVS & 0.0107 & 3.388 & 0.1 \\
CFS & -0.0015 & -0.101 & 92.0 \\
LTD & -0.0055 & -0.691 & 49.0 \\
SIZE & 0.0016 & 1.348 & 17.8 \\
ADVS & -0.0075 & -0.205 & 83.8 \\
BLOC & 0.0065 & 0.782 & 43.5 \\
INST & 0.0126 & 0.993 & 32.1 \\
Industry Dummies (IND 1 to IND 14$)$ & Yes & & \\
INSD & 0.0095 & 1.039 & 29.9 \\
\hline
\end{tabular}

Note: The dependent variable is research and development expenditure divided by sales (RDS). The independent variables are defined as follows:

EVS: (market value of equity + book value of long-term debt - book value of total assets)/sales

CFS: free cash flow divided by sales, where free cash flow equals operating income before depreciation

- interest expense - taxes - dividends.

LTD: long-term debt/(long-term debt + market value of equity).

SIZE: $\log$ (market value of equity).

ADVS: advertising expenses divided by sales.

BLOC: blockholders' share of common equity in \% (excluding insiders' blockholdings).

INST: institutional holdings in \% (excluding institutional blockholdings).

$\mathrm{IND}_{1}$ to $\mathrm{IND}_{14}$ : industry dummies.

INSD: insider holdings in \%.

calculation of ownership of officers and directors. Finally, Thomas (1995) uses the same 5 and $25 \%$ turning points for institutional ownership, insider ownership and 5\% block ownership in the same regression.

We observe that different models use different sets of control variables. The influence of control variables on the signs and significance levels of the piecewise variables is highlighted in Table 2 of Morck, Shleifer and Vishny (1988), which shows that without the control variables, the relation between Tobin's $\mathrm{Q}$ and board ownership when ownership is over $25 \%$ is insignificantly negative. When control variables such as R\&D expenses per dollar of assets are included the relation becomes weakly significantly positive.

The model used in Wruck (1989) is a modified MSV piecewise regression model in which the first differences in variables are used:

$$
\Delta y_{i}=\alpha_{1}+\beta_{1} x_{i 1}+\cdots+\beta_{k} x_{i k}+\theta_{1} \Delta z_{i 1}+\cdots+\theta_{p} \Delta z_{i p}+\varepsilon_{i}, \quad i=1, \ldots, n
$$

The piecewise variables, $\Delta z_{i 1}, \ldots, \Delta z_{i p}$ are defined as $\Delta z_{i j}=z_{i j}^{(a)}-z_{i j}^{(b)}$, where $z_{i j}^{(b)}$ and $z_{i j}^{(a)}$ are values of $z_{i j}$ before and after an event and are defined analogously as the $z_{i j}$ piecewise variables in the MSV model (Eq. (1)).

It is interesting to note that when Wruck (1989) takes the first difference of Morck, Shleifer and Vishny (1988) piecewise regression results to compare with her own results (see Table 7 in Wruck), she implicitly assumes that the control variables in Morck, Shleifer 
and Vishny model would disappear. This assumes that the values and the coefficients of the control variables remain unchanged before and after a private placement.

In another study of private placements by Hertzel and Smith (1993), the piecewise ownership variables as defined in Wruck (1989) are not significant. Hertzel and Smith explain that the contrasting results may be due to the smaller average firm size in their sample relative to that of Wruck (1989). However, it should be noted that Herzel and Smith (1993) include information variables such as book-to-market-equity in their models, which are not examined in Wruck (1989). They show that the information variables may have dominated the ownership variables. We suggest that the different results may be influenced by different control variables in the two studies.

Thomas (1995), Martin (1996) and Ghosh and Ruland (1998) adapted the MSV piecewise linear methodology in a logistic regression framework. Again, the issue of the number and positions of the turning points arises in these studies.

\section{2. $\quad$ Models with slope dummies}

Models with slope dummies to capture nonlinear effects are common in empirical studies. ${ }^{9}$ The following is a general representation of a model with slope dummies.

$$
y_{i}=\alpha_{1}+\beta_{1} x_{i 1}+\cdots+\beta_{k} x_{i k}+\theta_{1} D_{1} z_{i}+\cdots+\theta_{p} D_{p} z_{i}+\varepsilon_{i}, \quad i=1, \ldots, n
$$

where $D_{1}=1$ if $z_{i}<P_{1}$, and 0 elsewhere; $D_{j}=1$ if $z_{i} \in\left[P_{j-1}, P_{j}\right.$ ), and 0 elsewhere, for $j=2, \ldots, p-1$; and $D_{p}=1$ if $z_{i} \geq P_{p-1}$, and 0 elsewhere.

The slope dummy approach does not require that the various segments meet at the joint points, $P_{1}$ to $P_{p-1}$. This may be a more flexible model than the MSV piecewise regression model. However, researchers must decide whether there is any theoretical justification for discontinuities at the joint points. Similar to the MSV methodology, the slope dummy variables approach assumes known number and positions of the break points.

\subsection{Quadratic and higher order polynomial regression models}

The quadratic regression model used in numerous studies can be represented as follows:

$$
y_{i}=\alpha_{1}+\beta_{1} x_{i 1}+\cdots+\beta_{k} x_{i k}+\theta_{1} z_{i}+\theta_{2} z_{i}^{2}+\varepsilon_{i}, \quad i=1, \ldots, n
$$

The main advantage of the quadratic regression model over the MSV methodology is that the turning point is determined empirically. However, the quadratic model assumes that there is only one turning point. Further, it may not fit the data well if the nonlinear relationship is not smooth. Finally, the position of the turning point is sensitive to the inclusion of other variables in the model (as seen in McConnell and Servaes, 1990).

The quadratic regression model does not allow for multiple turning points. Since Morck, Shleifer and Vishny (1988) and Wruck (1989) suggest that there may be more than one turning point in the relationship between firm value and ownership variables, a higher order polynomial may be more appropriate. Short and Keasey (1999) indeed find a significant 
cubic functional relation between firm performance and managerial ownership for a sample of UK firms. Thus, as part of specification checks, it is important for researchers to examine higher order polynomial functional form. We discuss below a case where a cubic functional form (or a piecewise linear model) may be more appropriate. As discussed in Section 2.3 above, Schooley and Barney (1994) find a curvilinear relation between dividend yield and CEO stock ownership. The relation is negative below $15 \%$ ownership but is positive above the turning point. The authors argue that the positive relation above 15\% ownership can be explained by the notion that higher dividend payout can increase market scrutiny on the firm when management is perceived to be entrenched at a sufficiently high ownership level. Since the piecewise linear results in Morck, Shleifer and Vishny (1988) and Wruck (1989) show that the alignment-of-interests effects dominate the entrenchment effects when ownership is above $25 \%$, there may be another negative relation between dividend yield and CEO ownership at a higher ownership level.

The different model specifications in Slovin and Sushka (1993) and Wruck (1989) provide an interesting comparison. Slovin and Sushka (1993) report a quadratic relation between abnormal return at the announcement of the death of an insider blockholder and the level of inside blockholding, while Wruck (1989) finds a piecewise linear relation between abnormal return associated with private placement announcements and change in ownership concentration. Slovin and Sushka (1993) report that deaths of inside blockholders generally reduce ownership concentration. It would be interesting to examine whether the reduction in ownership concentration following the deaths of inside blockholders can explain the abnormal return by using Wruck's (1989) piecewise linear specification. Since the functional form for the change in firm value (as proxied by abnormal return) depends on the functional form of the firm value itself, the results of the two studies suggest some conflicting evidence on the impact of corporate ownership structure on firm value.

\subsection{The Fields and Mais' (1994) model}

Fields and Mais (1994) provide an alternative method of examining nonlinear relationship. They regress the slope of a function against the independent variable as follows:

$$
\frac{\Delta y_{i}}{\Delta z_{i}}=\alpha_{1}+\beta_{1} x_{i 1}+\cdots+\beta_{k} x_{i k}+\theta_{1} z_{i}+\varepsilon_{i}, \quad i=1, \ldots, n
$$

The dependent variable is the ratio of announcement-period abnormal return to change in management ownership. This model implicitly assumes that the relation between firm value $\left(y_{i}\right)$ and management ownership $\left(z_{i}\right)$ is quadratic. A significant relation between $\Delta y_{i} / \Delta z_{i}$ and $z_{i}$ implies a curvilinear relation between $y_{i}$ and $z_{i}$. Since the implicit model is a quadratic one, this methodology cannot accommodate multiple turning points.

\subsection{Switching regression models}

Allen and Cebenoyan (1991) use a switching regression model to examine structural changes in the relationship between bank acquisition and ownership structure. ${ }^{10}$ Their model has 
the following general form:

$$
y_{i}=\alpha_{1}+\beta_{1 j} x_{i 1}+\cdots+\beta_{k j} x_{i k}+\theta_{1 j} z_{1 i}+\cdots+\theta_{p j} z_{p i}+\varepsilon_{i}
$$

where $z_{1 i}, \ldots, z_{p i}$ are the $p$ switching variables, $j=\mathrm{I}$, II, III, IV,$\ldots$, are the regimes determined by the critical point(s) of the switching variables, and $x_{i 1}, \ldots, x_{i k}$ are the $k$ control variables. In Allen and Cebenoyan, the switching variables are the fraction of shares held by insiders and the fraction of shares held by the top five shareholders. Pantzalis, Kim and Kim (1998) apply a similar switching regression model to examine the relationship between market valuation of a firm and its equity ownership structure. The switching variables used are the percent of shares owned by insiders and the percent of shares owned by blockholders. Note that Allen and Cebenoyan (1991) and Pantzalis, Kim and Kim (1998) use two switching variables. With one switching point for each variable, there are four regimes. In Eq. (6) above, we are allowing more than two switching variables and hence there could be more than four regimes. ${ }^{11}$

The advantage of the switching regression model is that it does not impose a constant relationship between the switching variables and the dependent variable across different regimes. Furthermore, the critical values of the switching variables are endogenous, i.e., they are not pre-specified. However, the switching regression model has the same problem as the model with slope dummies in that various segments do not join.

\subsection{Simultaneous equation model}

Several researchers use simultaneous equation model in corporate finance research (see Boyle, Carter and Stover, 1998; Cho, 1998; Himmelberg, Hubbard and Palia, 1999). The need to use simultaneous equation model arises from the notion that insider ownership or other variables may be endogenous, instead of exogenously determined. Boyle, Carter and Stover (1998) examine a model where the number of antitakeover provisions and insider ownership are considered as endogenous variables. Cho's (1998) model assumes that insider ownership, corporate value and investment are endogenous. Himmelberg, Hubbard and Palia (1999) apply the model to panel data where time series and cross-section observations are pooled.

A simple simultaneous equation model involving two endogenous variables can be represented by the following equations:

$$
\begin{aligned}
& y_{i 1}=\alpha_{1}+\delta_{1} y_{i 2}+\beta_{11} x_{i 1}+\cdots+\beta_{1 k} x_{i k}+u_{i 1} \\
& y_{i 2}=\alpha_{1}+\delta_{2} y_{i 1}+\beta_{21} x_{i 1}+\cdots+\beta_{2 k} x_{i k}+u_{i 1}
\end{aligned}
$$

If we estimate a single equation like Eq. (7) ignoring the fact that $y_{2}$ is endogenous, then the estimator can be shown to be biased. Therefore, in the estimation the fact that both $y_{1}$ and $y_{2}$ are endogenous needs to be incorporated. In practice, the estimation is usually done by applying the two-stage least squares estimation technique, which involves the use of instrumental variables. 
The simultaneous equation model can accommodate nonlinear effects as discussed before in a single equation setup. For example, $y_{2}$ may be piecewise linear or quadratic. The discussions on the advantages and disadvantages of the various nonlinear specifications are also relevant to a simultaneous equation setup.

\section{Extensions}

In this section, we provide two possible extensions to the exiting methodologies used in detecting nonlinear relationship in corporate finance research: "residual analysis" and "nonlinearity with interaction effect."

\subsection{Residual analysis}

It is a well-established fact that a partial regression coefficient, in a multiple regression framework, can be obtained by running the regression of residuals. Consider the following regression equation:

$$
y_{i}=\beta_{1} x_{i 1}+\cdots+\beta_{k} x_{i k}+\theta_{1} z_{i 1}+\cdots+\theta_{p} z_{i p}+\varepsilon_{i}, \quad i=1, \ldots, n
$$

In matrix notation, the regression equation can be represented by

$$
Y=X \beta+Z \theta+\varepsilon
$$

where

$$
\begin{aligned}
& Y=\left[\begin{array}{c}
y_{1} \\
y_{2} \\
\vdots \\
y_{n}
\end{array}\right], \quad X=\left[\begin{array}{cccc}
x_{11} & x_{12} & \cdots & x_{1 k} \\
x_{21} & x_{22} & \cdots & x_{2 k} \\
\vdots & \vdots & \cdots & \vdots \\
x_{n 1} & x_{n 2} & \cdots & x_{n k}
\end{array}\right], \quad Z=\left[\begin{array}{cccc}
z_{11} & z_{12} & \cdots & z_{1 p} \\
z_{21} & z_{22} & \cdots & z_{2 p} \\
\vdots & \vdots & \cdots & \vdots \\
z_{n 1} & z_{n 2} & \cdots & z_{n p}
\end{array}\right], \\
& \beta=\left[\begin{array}{c}
\beta_{1} \\
\beta_{2} \\
\vdots \\
\beta_{k}
\end{array}\right], \quad \theta=\left[\begin{array}{c}
\theta_{1} \\
\theta_{2} \\
\vdots \\
\theta_{p}
\end{array}\right], \quad \text { and } \varepsilon=\left[\begin{array}{c}
\varepsilon_{1} \\
\varepsilon_{2} \\
\vdots \\
\varepsilon_{n}
\end{array}\right]
\end{aligned}
$$

Suppose that we are interested in the parameter vector $\theta$. We can obtain $\theta$ by estimating the regression Eq. (9). Alternatively, we can estimate $\theta$ by running the following regression:

$$
M Y=M Z \theta+u
$$

where $M=I_{n}-X\left(X^{\prime} X\right)^{-1} X^{\prime}$ is an idempotent matrix, and $M Y=Y-X\left(X^{\prime} X\right)^{-1} X^{\prime} Y$ and $M Z=Z-X\left(X^{\prime} X\right)^{-1} X^{\prime} Z$ are the residual vectors of the auxiliary regression Eqs. (12) 
and (13) respectively, as given below:

$$
\begin{aligned}
& Y=X \Phi_{1}+U_{1} \\
& Z=X \Phi_{2}+U_{2}
\end{aligned}
$$

Therefore, regression Eq. (11) is the regression of the residuals of regression Eq. (12) on the residuals of regression Eq. (13).

Regression Eq. (11) has the advantage that it represents the regression of $Y$ on Zafter the linear impact of $X$ is removed from both $Y$ and $Z .{ }^{12}$ This is what we would like to achieve when introducing control variables in a regression relationship. For example, if we use $X$ to represent the control variables, then regression (11) represents the relationship between $Y$ and $Z$ after eliminating the linear effect of the control variables. One advantage of using Eq. (11) is a reduction in dimensionality. Graphical visualization is also made easier. For example, when $Z$ consists of a single variable (e.g., insider ownership where $Y$ represents firm value), Eq. (11) would represent the relationship between two variables where two-dimensional graphical visualization is possible.

Since the variables used in auxiliary regression (11) are residuals, we call the analysis "residual analysis." The residual analysis can be applied to examine several types of nonlinear relationships. Consider a case where $Z$ consists of a single variable denoted by $z$ and the relationship is a quadratic one as given below:

$$
y_{i}=\beta_{1} x_{i 1}+\cdots+\beta_{k} x_{i k}+\theta_{1} z+\theta_{2} z^{2}+\varepsilon_{i}
$$

Then, the relationship in residual form can be written as

$$
M Y=M Z_{1} \theta_{1}+M Z_{2} \theta_{2}+u
$$

where

$$
Z_{1}=\left[\begin{array}{c}
z_{1} \\
z_{2} \\
\vdots \\
z_{n}
\end{array}\right] \quad \text { and } \quad Z_{2}=\left[\begin{array}{c}
z_{1}^{2} \\
z_{2}^{2} \\
\vdots \\
z_{n}^{2}
\end{array}\right]
$$

Therefore, the quadratic relationship, in the presence of control variables, can be estimated using the residual regression.

The residual regression can also be applied to a switching regression with known switching points. Consider the following regression, with switching point at $d_{1}$ :

$$
y_{i}=\beta_{1} x_{i 1}+\cdots+\beta_{k} x_{i k}+\theta_{1} z+\theta_{2} D\left(z, d_{1}\right) z+\varepsilon_{i}
$$


where $D\left(z, d_{1}\right)$ is a dummy variable defined as

$$
D\left(z, d_{1}\right)=\left\{\begin{array}{ll}
0, & \text { for } z<d_{1} \\
1, & \text { for } z \geq d_{1}
\end{array} .\right.
$$

Then, the residual regression is given by

$$
M Y=M Z_{1} \theta_{1}+M Z_{d_{1}} \theta_{2}+u
$$

where $Z_{1}$ is defined as before and $Z_{d_{1}}$ is the vector representation of the variable $D\left(z, d_{1}\right) z$.

In general, any nonlinear relationship can be estimated using the residual method so long as the relationship is linear in parameters. Furthermore, in the residual analysis the grid search technique can be used to find the unknown switching points in a switching regression. Due to the reduction in dimensionality, the residual analysis is computationally efficient when there is a need to estimate the model many times. For example, when using grid search technique in estimating switching points, the model needs to be estimated many times. In this case, the residual analysis will be computationally efficient. Finally, it is important to note that the residual analysis can be applied to the simultaneous equation model with some minor modifications.

\subsection{Nonlinearity with interaction effect}

Even though nonlinear models are widely applied in corporate finance research, the interaction effect seems to be less well researched. However, interaction effects can be quite important. For example, in the analysis of the effect of the insider ownership on the firm value, it might be important to look at the interaction effect of the institutional ownership. ${ }^{13}$

Morck, Shleifer and Vishny (1988) show that when insider ownership is very low, the alignment effect plays an important role. However, after a certain level of insider ownership, the entrenchment effect will dominate. Eventually, at very high levels of the insider ownership, the alignment effect will again dominate. However, it is possible that when the level of institutional ownership is high, the managerial entrenchment effect could be reduced significantly because of the monitoring effect of institutional ownership. This could result in a situation where the entrenchment effect will never dominate the alignment effect.

Allen and Cebenoyan (1991) analyze interaction effects of two ownership variables (insider shareholdings and shareholder concentration) using a switching regression methodology. We can also analyze interaction effects using models that explicitly incorporate the interaction effect. One example of the models is given below: ${ }^{14}$

$$
\begin{aligned}
y= & \beta_{1} x_{1}+\cdots+\beta_{k} x_{k}+\theta_{1} z_{1}+\theta_{2} z_{1}^{2}+\theta_{3} z_{1}^{3}+\gamma_{1} z_{1} z_{2}+\gamma_{2} z_{1} z_{2}^{2} \\
& +\phi_{1} z_{2}+\phi_{2} z_{2}^{2}+\phi_{3} z_{2}^{3}+e
\end{aligned}
$$

As before, $x_{i}$ 's represent the control variables. In this model, we are mainly interested in the effect of $z_{1}$ on $y$. Coefficients $\gamma_{1}$ and $\gamma_{2}$ represent the interaction effect of $z_{1}$ and $z_{2}$. 
This allows the effect of $z_{1}$ on $y$ to be nonlinearly dependent on $z_{2}$. This is clear from the partial derivative of $y$ with respect to $z_{1}$ :

$$
\frac{\partial y}{\partial z_{1}}=\theta_{1}+2 \theta_{2} z_{1}+3 \theta_{3} z_{1}^{2}+\gamma_{1} z_{2}+\gamma_{2} z_{2}^{2}
$$

This model allows the sign of the partial derivative of $y$ with respect to $z_{1}$ to change depending on the value of $z_{2}$. One possible application of such model would be to analyze the effect of insider ownership $\left(z_{1}\right)$ and institutional ownership $\left(z_{2}\right)$ on the value of the firm (y).

As in the switching regression model, our "nonlinearity with interaction effect" method does not impose a constant relationship between the switching variables and the dependent variable across different regimes. Furthermore, the critical values of the switching variables are endogenous. In addition, our method has several advantages relative to the switching regression model. Our method allows a smooth transition from one segment to another segment (see figure 1 in the next section). It allows the interaction effect to be smooth. ${ }^{15}$ Finally, by including a higher order polynomial our method can allow more than one turning point. The above approach to accommodate nonlinear interaction effects can also be implemented in a simultaneous equation framework.

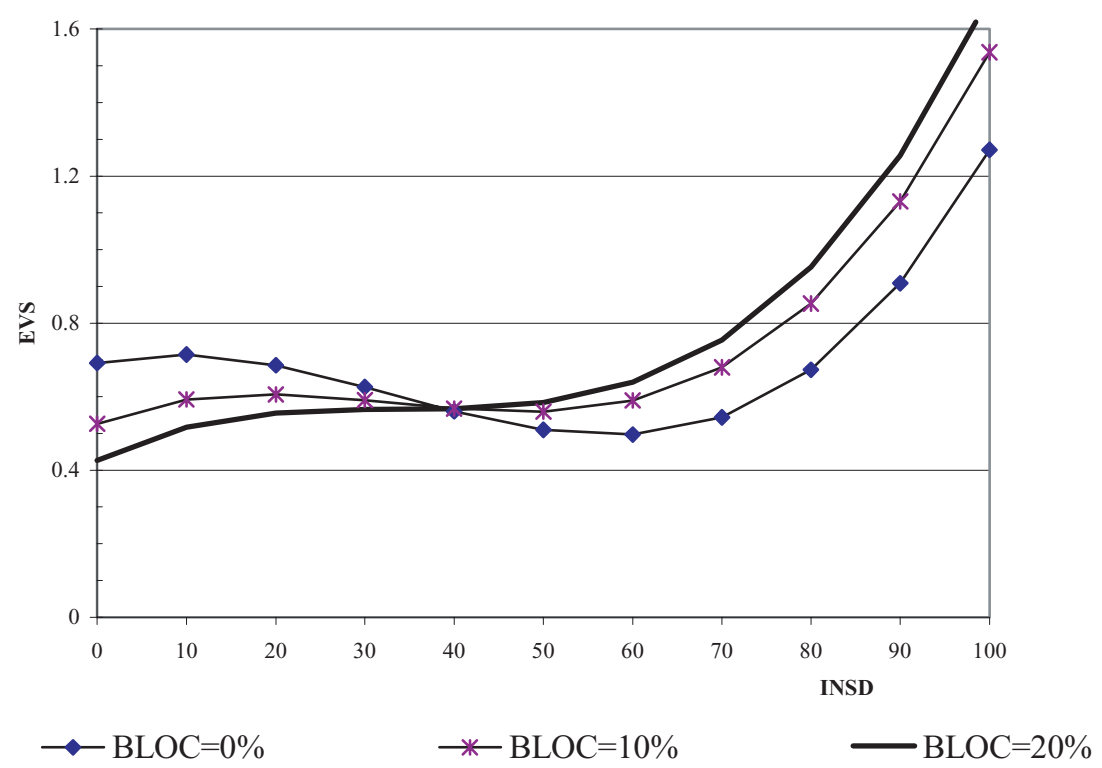

Figure 1. Interaction effect of block ownership on the nonlinear relationship between firm value and insider ownership. EVS: (market value of equity + book value of long-term debt - book value of total assets)/sales; INSD: insider holdings in \%; BLOC: blockholders' share of common equity in \% (excluding insiders' blockholdings). (Note: The figure is drawn based on the estimated parameters of Eq. (23) with all control variables set to zero.) 


\section{Empirical analysis}

\subsection{Application of residual analysis}

In this section, we will apply the residual analysis in the estimation of the nonlinear dependence of R\&D investment on the insider ownership. ${ }^{16}$ We will estimate three versions of the investment function: (i) with no switching point, (ii) with one switching point, and (iii) with two switching points. In Eq. (20), only the linear effect of insider ownership is included. In Eq. (21), a piecewise linear function with one switching point $\left(I_{1}\right)$ is used to express the nonlinear effect of insider ownership. Equation (22) shows a piecewise linear function with two switching points $\left(I_{1}\right.$ and $\left.I_{2}\right) .{ }^{17}$ The data set used in this analysis is the same as that used in Pantzalis, Kim and Kim (1998). ${ }^{18}$ All data are end-of-year data for 1987.

With no switching point:

$$
\begin{aligned}
\mathrm{RDS}= & \beta_{0}+\beta_{1} \mathrm{EVS}+\beta_{2} \mathrm{CFS}+\beta_{3} \mathrm{LTD}+\beta_{4} \mathrm{SIZE}+\beta_{5} \mathrm{ADVS}+\beta_{6} \mathrm{BLOC} \\
& +\beta_{7} \mathrm{INST}+\sum_{j=1}^{14} \beta_{7+j} \mathrm{IND}_{j}+\theta \mathrm{INSD}+\text { Error }
\end{aligned}
$$

With one switching point:

$$
\begin{aligned}
\mathrm{RDS}= & \beta_{0}+\beta_{1} \mathrm{EVS}+\beta_{2} \mathrm{CFS}+\beta_{3} \mathrm{LTD}+\beta_{4} \mathrm{SIZE}+\beta_{5} \mathrm{ADVS}+\beta_{6} \mathrm{BLOC} \\
& +\beta_{7} \mathrm{INST}+\sum_{j=1}^{14} \beta_{7+j} \mathrm{IND}_{j}+\theta_{1} \mathrm{INSD}_{1}+\theta_{2} \mathrm{INSD}_{2}+\text { Error }
\end{aligned}
$$

where

$$
\mathrm{INSD}_{1}=\left\{\begin{array}{ll}
\mathrm{INSD}, & \text { if INSD }<I_{1} \\
I_{1}, & \text { if INSD } \geq I_{1}
\end{array},\right.
$$

and

$$
\mathrm{INSD}_{2}=\left\{\begin{array}{ll}
0, & \text { if INSD }<I_{1} \\
\mathrm{INSD}-I_{1}, & \text { if INSD } \geq I_{1}
\end{array} .\right.
$$

With two switching points:

$$
\begin{aligned}
\mathrm{RDS}= & \beta_{0}+\beta_{1} \mathrm{EVS}+\beta_{2} \mathrm{CFS}+\beta_{3} \mathrm{LTD}+\beta_{4} \mathrm{SIZE}+\beta_{5} \mathrm{ADVS}+\beta_{6} \mathrm{BLOC} \\
& +\beta_{7} \mathrm{INST}+\sum_{j=1}^{14} \beta_{7+j} \mathrm{IND}_{j}+\theta_{1} \mathrm{INSD}_{1}+\theta_{2} \mathrm{INSD}_{2}+\theta_{3} \mathrm{INSD}_{3}+\text { Error }
\end{aligned}
$$


where

$$
\begin{aligned}
& \mathrm{INSD}_{1}= \begin{cases}\mathrm{INSD}, & \text { if INSD }<I_{1} \\
I_{1}, & \text { if INSD } \geq I_{1}\end{cases} \\
& \mathrm{INSD}_{2}= \begin{cases}0, & \text { if INSD }<I_{1} \\
\mathrm{INSD}-I_{1}, & \text { if } I_{1} \leq \mathrm{INSD}<I_{2} \\
I_{2}-I_{1}, & \text { if INSD } \geq I_{2}\end{cases} \\
& \mathrm{INSD}_{3}= \begin{cases}0, & \text { if INSD }<I_{2} \\
\mathrm{INSD}-I_{2}, & \text { if INSD } \geq I_{2}\end{cases}
\end{aligned}
$$

The variable definitions are as follows:

RDS: R\&D expenditures divided by sales

EVS: (market value of equity + book value of long-term debt - book value of total assets)/sales

CFS: free cash flow divided by sales, where free cash flow equals operating income before depreciation - interest expense - taxes - dividends

LTD: long-term debt/(long-term debt + market value of equity)

SIZE: $\log$ (market value of equity)

ADVS: advertising expenses divided by sales

BLOC: blockholders' share of common equity in \% (excluding insiders' blockholdings)

INST: institutional holdings in \% (excluding institutional blockholdings)

$\mathrm{IND}_{1}$ to $\mathrm{IND}_{14}$ : industry dummies

INSD: insider holdings in \%

It is important to note that the switching points in Eqs. (21) and (22) are estimated rather than pre-determined. The locations of switching points are estimated using the grid search technique. The number and locations of switching points are chosen based on the log likelihood function.

Table 3. Log likelihood ratio test in determining the number of switching points

\begin{tabular}{llll}
\hline & Log likelihood function & Likelihood ratio statistic & $P$-value (\%) \\
\hline $\begin{array}{l}\text { No switching point } \\
\begin{array}{l}\text { Single switching point at } 10.7 \% \\
\quad \text { insider ownership }\end{array}\end{array}$ & 1130.05 & 11.32 & 0.08 \\
$\begin{array}{l}\text { Two switching points at } 12.6 \% \\
\text { and } 19.7 \% \text { insider ownership }\end{array}$ & 1136.42 & 1.42 & 23.34 \\
\hline
\end{tabular}

Note: This table presents the log likelihood ratio test in determining the number of switching points in Eqs. (20) to (22). The log likelihood ratio test statistic is given by $2\left(\log _{e}\left(L_{i+1}\right)-\log _{e}\left(L_{i}\right)\right)$ where $\log _{e}\left(L_{i}\right)$ is the value of the log likelihood function with $i$ number of switching points. 
Table 2 summarizes the results of the estimation of Eq. (20). The results show that only EVS (a proxy for Tobin's Q) is significant. All other variables, including the insider ownership (INSD), are not significant. From the likelihood ratio test, as reported in Table 3, there is strong evidence of one switching point. The likelihood ratio statistic for two switching points is insignificant, indicating a single switching point.

Table 4. Cross-sectional regression of research and development expenditure: Estimation of Eqs. (21) and (22)

\begin{tabular}{lccc}
\hline Independent variables & Coefficient & $T$-ratio & $P$-value (\%) \\
\hline Estimation of Eq. (21): Single switching point at $10.7 \%$ & \\
INSD $_{1}$ & 0.1404 & 3.530 & 0.04 \\
INSD $_{2}$ & -0.1210 & -1.110 & 26.70 \\
Estimation of Eq. (22): Two switching points at $12.6 \%$ and & $19.7 \%$ \\
INSD $_{1}$ & 0.1535 & 3.565 & 0.04 \\
INSD $_{2}$ & -0.1172 & -1.497 & 13.44 \\
INSD $_{3}$ & -0.0014 & -0.097 & 92.24 \\
\hline
\end{tabular}

Note: The control variables are the same as the independent variables given in Table 2 except the inside ownership (INSD). Since we use residual analysis, the estimation of the coefficients of the control variables is eliminated.

Table 5. Estimation of Eq. (23)

\begin{tabular}{|c|c|c|c|}
\hline Independent variables & Coefficient & $T$-ratio & $P$-value $(\%)$ \\
\hline Constant & 0.691 & 6.155 & 0.00 \\
\hline RDS & 2.123 & 3.505 & 0.05 \\
\hline CFS & -0.115 & -0.546 & 58.51 \\
\hline LTD & -0.978 & -9.553 & 0.00 \\
\hline ADVS & -0.078 & -0.152 & 87.92 \\
\hline INST & 0.225 & 1.593 & 11.18 \\
\hline Industry Dummies ( $\mathrm{IND}_{1}$ to $\mathrm{IND}_{14}$ ) & Yes & & \\
\hline INSD & 0.565 & 0.863 & 38.86 \\
\hline $\mathrm{INSD}^{2}$ & -3.727 & -1.730 & 8.42 \\
\hline INSD $^{3}$ & 3.742 & 1.977 & 4.86 \\
\hline $\mathrm{INSD} \times \mathrm{BLOC}$ & 5.204 & 2.607 & 0.94 \\
\hline $\mathrm{INSD} \times \mathrm{BLOC}^{2}$ & -9.015 & -2.204 & 2.79 \\
\hline BLOC & -2.009 & -2.953 & 0.33 \\
\hline BLOC $^{2}$ & 3.787 & 1.586 & 11.33 \\
\hline BLOC $^{3}$ & -1.904 & -0.897 & 37.04 \\
\hline
\end{tabular}

Note: The dependent variable is EVS, which is defined as (market value of equity + book value of long-term debt - book value of total assets)/sales. The independent variables are defined as follows: RDS: R\&D expenditures divided by sales.

CFS: free cash flow divided by sales, where free cash flow equals operating income before depreciation - interest expense - taxes - dividends.

LTD: long-term debt/(long-term debt + market value of equity).

ADVS: advertising expenses divided by sales.

INST: institutional holdings in \% (excluding institutional blockholdings).

$\mathrm{IND}_{1}$ to $\mathrm{IND}_{14}$ : industry dummies.

INSD: insider holdings in \%.

BLOC: blockholders' share of common equity in \% (excluding insiders' blockholdings). 


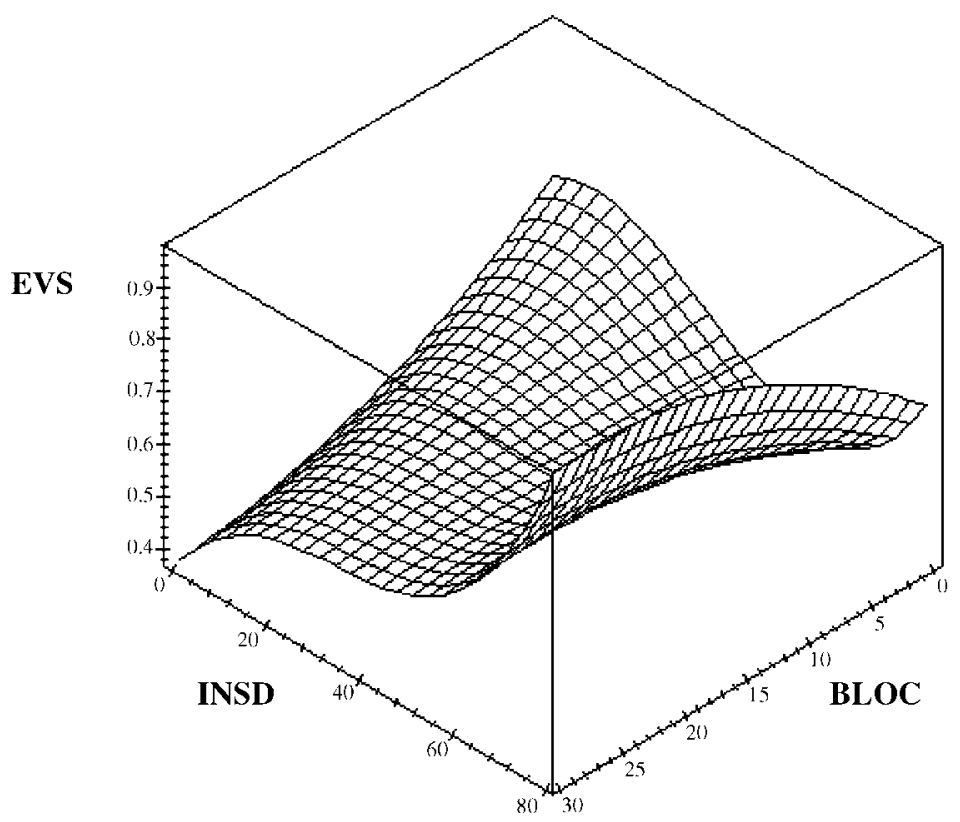

Figure 2. The nonlinear relationship between firm value, insider ownership and block ownership. EVS: (market value of equity + book value of long-term debt - book value of total assets)/sales; INSD: insider holdings in $\%$; BLOC: blockholders' share of common equity in \% (excluding insiders' blockholdings). (Note: The figure is drawn based on the estimated parameters of Eq. (23) with all control variables set to zero.)

Table 4 summarizes the results of the estimation of Eqs. (21) and (22). The single switching point in Eq. (21) is found to be at $10.7 \%$ insider ownership, whereas the two switching points in Eq. (22) are at 12.6 and $19.7 \%$ insider ownership. The results from the estimation of Eq. (21) show that R\&D investment increases with the level of insider ownership when insider ownership is below $10.7 \%$. However, for insider ownership above $10.7 \%$, R\&D investment does not significantly change with insider ownership. The results from the estimation of Eq. (22) with two switching points show that R\&D investment increases with insider ownership up to the level of $12.6 \%$ insider ownership. Beyond $12.6 \%$ and up to $19.7 \%$ insider ownership, R\&D investment decreases with increase in insider ownership. However, this negative relationship is significant only at $15 \%$ level. Beyond $19.7 \%$ insider ownership, the relationship between insider ownership and R\&D investment is insignificant. These results are similar to those obtained by Cho (1998) although the switching points are different, which could be due to the different variables and data sets used. However, since the empirical results suggest that there is only one switching point, our conclusion regarding the R\&D investment function should be based on the estimation of Eq. (21).

\subsection{Application of nonlinear effect with interaction}

As an example of nonlinear effect with interaction, we estimate the relationship between firm value and ownership structure. Specifically, the following equation is 
estimated:

$$
\begin{aligned}
\text { EVS }= & (\text { control variables })+\theta_{1} z_{1}+\theta_{2} z_{1}^{2}+\theta_{3} z_{1}^{3}+\gamma_{1} z_{1} z_{2}+\gamma_{2} z_{1} z_{2}^{2} \\
& +\phi_{1} z_{2}+\phi_{2} z_{2}^{2}+\phi_{3} z_{2}^{3}+e
\end{aligned}
$$

where $z_{1}=$ INSD and $z_{2}=$ BLOC. The control variables used are RDS, CFS, LTD, ADVS, INST, and the 14 industry dummies.

Table 5 and figures 1 and 2 summarize the empirical results of the estimation of Eq. (23). The results show that the effect of managerial entrenchment exists only for a low level of block ownership. For example, at 10 percent of block ownership, the entrenchment effect is very small and it completely disappears when the block ownership reaches 20 percent. Therefore, the evidence suggests that the nonlinear relationship between the insider ownership and firm value depends on the level of block ownership. A high level of block ownership seems to be enough to eliminate the entrenchment effect.

\section{Concluding remarks}

Nonlinear model specifications are prevalent in extant corporate finance literature. In this paper, we provide a detailed review of the theory and evidence in these studies. We note the diversity in methodologies used to detect nonlinearity in these studies. We then discuss the strengths and weaknesses of each of these methods.

Based on our review, several observations can be made. First, since the work of Morck, Shleifer and Vishny (1988), the use of piecewise linear regression has become commonplace in corporate finance research, especially when the variable concerned is related to ownership structure. Many of these studies use the 'standard' turning points of 5 and 25\% as in Morck, Shleifer and Vishny (1988) without evidence of specification checks. As shown in Section 2, the number and locations of turning points are far from fixed. In fact, our review shows that several papers do report different turning points in the relation between firm value and managerial ownership, both in cross-sectional and event studies. Studies that use the same turning points as in Morck, Shleifer and Vishny (1988) may not find significant results for certain segments of the variable. These studies may have suffered from model specification error. Further, we also note that different control variables used in different studies may have an impact on the nonlinear results.

Second, using alternative methodology may provide new insights on issues where mixed results have been previously documented. For example, when managerial ownership is endogenously determined in a simultaneous equation model as in Cho (1988), the relation between managerial ownership and firm value becomes insignificant. Another example is that provided by Halpern et al. (1999) where cluster analysis is used to identify two distinct groups of poorly performing firms going private through leveraged buyouts. They find that the motivations and post-transaction actions of the two groups are different and suggest that the mixed results in previous studies may be due to the mix of LBO firms in the samples.

Third, some studies do not find evidence of nonlinear relation when one is expected. The lack of results may be due to the methodology used. For example, Mikkelson, Partch and Shah (1997) find that the post-IPO firm performance is unrelated to insider ownership 
and insider ownership squared. Lie (2000) does not find evidence supporting the notion that, among firms that have high excess cash and low growth opportunities, the abnormal return associated with announcements of special dividends and self-tender offers should be stronger for those with poor control mechanisms. The author uses the standard 5 and 25\% break points for the dummy ownership variable.

Finally, as shown in Cebenoyan, Cooperman and Register (1995) and Short and Keasey (1999), the functional form of nonlinear relation may be dependent on the regulatory or institutional environment. When one examines international data or those related to regulated industries, it is important to explore alternative model specifications or methodologies.

In this paper, we provide two possible methodological extensions to examine nonlinear relationships in corporate finance research. The first method, which is known as residual analysis, uses the auxiliary regression technique. This technique allows the researchers to take away the linear effect of the control variables and concentrate on the residuals that are free of the effect of the control variables. This method, in addition to reducing the dimensionality, makes graphical visualization possible where there are one or two switching variables. This is true regardless of the number of control variables. Furthermore, the residual analysis will be computationally efficient when using grid search technique in finding switching points. As an example, we apply the residual analysis in the estimation of R\&D investment function.

The second method involves modeling the interaction effect between variables to test the effect of one switching variable on another switching variable. This method allows a smooth transition from one segment to another segment and enables the interaction effect to be smooth. By including a higher order polynomial, this method also allows more than one turning point. A version of the model with interaction effect is applied in the estimation of the impact of insider ownership on Tobin's Q. We find that the well-known entrenchment effect disappears when the block ownership is sufficiently high.

\section{Acknowledgments}

The authors wish to thank James Booth and seminar participants at the 2001 FMA Annual Meeting, the Seventh Conference on Pacific Basin Finance, Economics and Accounting, and Annual Research Conference in Finance and Financial Market in the 21st Century for helpful comments. Any errors are the authors'.

\section{Notes}

1. See, for example, Byrd and Hickman (1992), Bagnani et al. (1994), Opler et al. (1999), Joh (2003) and others.

2. For example, Thomas (1995) uses the same turning points (5 and 25\%) for each of the three different ownership measures in a single model.

3. Hudson, Jahera and Lloyd (1992) show that, after controlling for firm size and earnings to price ratio, the relation between excess returns and insider ownership is negative but insignificant in the 0 to $5 \%$ insider ownership range, positive but insignificant in the 5 to $25 \%$ range, and significantly positive beyond $25 \%$.

4. Daines (2001) also reports a quadratic relation between director and officer ownership and Tobin's Q. Woidtke (2003) reports a quadratic relation between insider ownership and industry-adjusted Q. 
5. An earlier paper by Kole (1995) also examines the differences in data sources used in ownership studies and suggests that differences in firm size can account for the reported differences in results.

6. To allow for a possible nonlinear relation, the authors divide the sample firms into three institutional ownership groups using two methods. The first is the equal-groups method, whereby firms are divided into three equal groups of low, intermediate, and high institutional ownership. The second method splits the sample into three groups using break points of 5 and $30 \%$, which are pre-determined.

7. Lee, Wu and Djarraya (1987) propose an integrated model consistent with the practical decision process to characterize the dividend adjustment process. Marquardt's (1963) nonlinear regression method is used to estimate the parameters of the integrated model. They show that the integrated model better explains the firm's dividend decision process.

8. The term 'piecewise regression' was first used in McGee and Carleton (1970). The MSV piecewise regression model is similar to the linear spline function discussed in Johnston (1984).

9. Kennedy, Lakonishok and Shaw (1992) use the term 'piecewise linear model' to describe a model in which nonlinearity is accommodated by using a set of slope dummies.

10. The switching regression model follows that of Goldfeld and Quandt (1973).

11. One can split a full sample into different regimes by using the cluster analysis as is done in Halpern, Kieschnick and Rotenberg (1999). The authors hypothesize that there are two types of poorly performing firms going private through leveraged buyout. One group consists of firms in which managers own an insignificant fraction of their firm's stock and are vulnerable to a hostile takeover. The other group consists of firms in which managers own a significant fraction of their firm's stock and so face little risk of hostile takeover. They use cluster analysis to separate their sample of leveraged buyout firms into two clusters according to managerial ownership and perform analysis on these groups separately. The cluster analysis technique is described in Hartigan and Wong (1979).

12. $M Y$ represents the component of $Y$ remaining after the linear impact of $X$ is taken out. Similarly, $M Z$ represents component of $Z$ after the linear impact of $X$ is removed.

13. For example, McConnell and Servaes (1990) show that the inclusion of institutional ownership in the regression model can increase the turning point in the quadratic relation between the inside ownership variable and firm value.

14. Halpern, Kieschnick and Rotenberg (1999) consider a simplified version of interaction effect where $\theta_{2}=$ $\theta_{3}=0$ and $\phi_{1}=\phi_{2}=\phi_{3}=0$.

15. The switching regression model also allows interaction effect, but the switching from one regime to another is not smooth.

16. A nonlinear relation between insider ownership and investment (capital expenditure or R\&D expenditure) is estimated by Cho (1998).

17. The equation can easily be modified to allow more than two switching points.

18. We thank the authors for their permission to use the data set in this paper.

\section{References}

Aggarwal, R., L. Krigman and K. Womack, "Strategic IPO Underpricing, Information Momentum, and Lockup Expiration Selling.” Journal of Financial Economics 66, 105-137 (2002).

Alangar, S., C. Bathala and R. Rao, "The Effect of Institutional Interest on the Information Content of Dividendchange Announcements.” Journal of Financial Research 22, 429-448 (1999).

Allen, L. and A. Cebenoyan, "Bank Acquisitions and Ownership Structure: Theory and Evidence." Journal of Banking and Finance 15, 425-448 (1991).

Anderson, R. and D. Lee, "Ownership Studies: The Data Source Does Matter.” Journal of Financial and Quantitative Analysis 32, 311-329 (1997).

Anderson, R., S. Mansi and D. Reeb, "Founding Family Ownership and the Agency Cost of Debt." Journal of Financial Economics 68, 263-285 (2003).

Anderson, R. and D. Reeb, "Founding-Family Ownership and Firm Performance." Journal of Finance 58, 13011328 (2003) 
Bae, S., D. Klein and R. Padmaraj, "Event Risk Bond Covenants, Agency Costs of Debt and Equity, and Stockholder Wealth.” Financial Management 23, 28-41 (1994).

Bagnani, E., N. Milonas, A. Saunders and N. G. Travlos, "Managers, Owners, and the Pricing of Risky Debt: An Empirical Analysis.” Journal of Finance 49, 453-477 (1994).

Barclay, M. and C. Smith, Jr., "The Maturity Structure of Corporate Debt.” Journal of Finance 50, 609-631 (1995).

Boyle, G., R. Carter and R. Stover, "Extraordinary Antitakeover Provisions and Insider Ownership Structure: The Case of Converting Savings and Loans." Journal of Financial and Quantitative Analysis 33, 291-304 (1998).

Brous, P. and O. Kini, "The Valuation Effects of Equity Issues and the Level of Institutional Ownership: Evidence from Analysts’ Earnings Forecasts.” Financial Management 23, 33-46 (1994).

Byrd, J. and K. Hickman, "Do Outside Directors Monitor Managers? Evidence from Tender Offer Bids.” Journal of Financial Economics 32, 195-221 (1992).

Cebenoyan, A., E. Cooperman and C. Register, "Deregulation, Reregulation, Equity Ownership, and S\&L Risktaking." Financial Management 24, 63-76 (1995).

Cho, M., "Ownership Structure, Investment, and the Corporate Value: An Empirical Analysis." Journal of Financial Economics 47, 103-121 (1998).

Cook, D. and J. Easterwood, "Poison Put Bonds: An Analysis of Their Economic Role." Journal of Finance 49, 1905-1920 (1994)

Daines, R., “Does Delaware Law Improve Firm Value?” Journal of Financial Economics 62, 525-558 (2001)

Demsetz, H., "The Structure of Ownership and the Theory of the Firm." Journal of Law and Economics 26, 375-390 (1983).

Denis, D., D. Denis and A. Sarin, “Agency Problems, Equity Ownership, and Corporate Diversification.” Journal of Finance 52, 135-160 (1997a).

Denis, D., D. Denis and A. Sarin, “Ownership Structure and Top Executive Turnover." Journal of Financial Economics 45, 193-221 (1997b).

Diamond, D., "Debt Maturity Structure and Liquidity Risk.” Quarterly Journal of Economics 106, 709-737 (1991).

Fama, E. and M. Jensen, "Separation of Ownership and Control." Journal of Law and Economics 26, 301-325 (1983).

Fields, L. and E. Mais, "Managerial Voting Rights and Seasoned Public Equity Issues.” Journal of Financial and Quantitative Analysis 29, 445-457 (1994).

Ghosh, A. and W. Ruland, "Managerial Ownership, the Method of Payment for Acquisitions, and Executive Job Retention.” Journal of Finance 53, 785-798 (1998).

Goldfeld, S. and R. Quandt, "The Estimation of Structural Shifts by Switching Regressions." Annals of Economic and Social Measurement 2, 475-485 (1973).

Halpern, P., R. Kieschnick and W. Rotenberg, "On the Heterogeneity of Leveraged Going Private Transactions." Review of Financial Studies 12, 281-309 (1999).

Hartigan, J. and M. Wong, “A K-means Clustering Algorithm: Algorithm AS 126.” Applied Statistics 28, 126-130 (1979).

Hertzel, M. and R. Smith, "Market Discounts and Shareholder Gains for Placing Equity Privately." Journal of Finance 48, 459-485 (1993).

Himmelberg, C., R. Hubbard and D. Palia, "Understanding the Determinants of Managerial Ownership and the Link Between Ownership and Performance.” Journal of Financial Economics 53, 353-384 (1999).

Holderness, C., R. Kroszner and D. Sheehan, "Were the Good Old Days That Good? Changes in Managerial Stock Ownership Since the Great Depression.” Journal of Finance 54, 435-469 (1999).

Hudson, C., J. Jahera, Jr. and W. Lloyd, "Further Evidence on the Relationship Between Ownership and Performance." Financial Review 27, 227-239 (1992).

Jensen, M. and W. Meckling, "Theory of the Firm: Managerial Behavior, Agency Costs and Ownership Structure.” Journal of Financial Economics 3, 305-360 (1976).

Joh, S., "Corporate Governance and Firm Profitability: Evidence from Korea before the Economic Crisis." Journal of Financial Economics 68, 287-322 (2003).

Johnston, J., Econometric Methods. New York, NY: McGraw-Hill, 1984. 
Kennedy, D., J. Lakonishok and W. Shaw, "Accommodating Outliers and Nonlinearity in Decision Models." Journal of Accounting, Auditing \& Finance 7, 161-193 (1992).

Kole, S., "Measuring Managerial Equity Ownership: A Comparison of Sources of Ownership Data." Journal of Corporate Finance 1, 413-435 (1995).

Lee, C., C. Wu and M. Djarraya, "A Further Empirical Investigation of the Dividend Adjustment Process.” Journal of Econometrics 35, 267-285 (1987).

Leland, H. and D. Pyle, "Information Asymmetries, Financial Structure, and Financial Intermediation." Journal of Finance 32, 371-387 (1977).

Lie, E., "Excess Funds and Agency Problems: An Empirical Study of Incremental Cash Distributions." Review of Financial Studies 13, 219-248 (2000).

Loderer, C. and K. Martin, "Executive Stock Ownership and Performance: Tracking Faint Traces." Journal of Financial Economics 45, 223-255 (1997).

Marquardt, D., “An Algorithm for Least-squares Estimation of Non-linear Parameters.” Journal of SIAM 2, 431441 (1963).

Martin, K., "The Method of Payment in Corporate Acquisitions, Investment Opportunities, and Management Ownership.” Journal of Finance 51, 1227-1246 (1996).

McConnell, J. and H. Servaes, “Additional Evidence on Equity Ownership and Corporate Value." Journal of Financial Economics 27, 595-612 (1990).

McGee, V. and W. Carleton, "Piecewise Regression." Journal of the American Statistical Association 65, 11091124 (1970).

McWilliams, V., "Managerial Share Ownership and the Stock Price Effects of Antitakeover Amendment Proposals." Journal of Finance 45, 1627-1640 (1990).

Mikkelson, W., M. Partch and K. Shah, "Ownership and Operating Performance of Companies That Go Public." Journal of Financial Economics 44, 281-308 (1997).

Morck, R., A. Shleifer and R. Vishny, "Management Ownership and Market Valuation: An Empirical Analysis." Journal of Financial Economics 20, 293-315 (1988).

Opler, T., L. Pinkowitz, R. Stulz and R. Williamson, "The Determinants and Implications of Corporate Cash Holdings." Journal of Financial Economics 52, 3-46 (1999).

Pantzalis, C., C. Kim and S. Kim, "Market Valuation and Equity Ownership Structure: The Case of Agency Conflict Regimes." Review of Quantitative Finance and Accounting 11, 249-268 (1998).

Rosenstein, S. and J. Wyatt, "Inside Directors, Board Effectiveness, and Shareholder Wealth.” Journal of Financial Economics 44, 229-250 (1997).

Roth, G. and G. McDonald, "Shareholder-Management Conflict and Event Risk Covenants." Journal of Financial Research 22, 207-226 (1999).

Rozeff, M., "Growth, Beta and Agency Costs as Determinants of Dividend Payout Ratios." Journal of Financial Research 5, 249-259 (1982).

Schooley, D. and L. Barney, Jr., "Using Dividend Policy and Managerial Ownership to Reduce Agency Costs." Journal of Financial Research 17, 363-373 (1994).

Short, H. and K. Keasey, "Managerial Ownership and the Performance of Firms: Evidence From the UK." Journal of Corporate Finance 5, 79-101 (1999).

Slovin, M. and M. Sushka, "Ownership Concentration, Corporate Control Activity, and Firm Value: Evidence from the Death of Inside Blockholders.” Journal of Finance 48, 1293-1321 (1993).

Slovin, M., M. Sushka and K. Lai, "Alternative Flotation Methods, Adverse Selection, and Ownership Structure: Evidence From Seasoned Equity Issuance in the U.K." Journal of Financial Economics 57, 157-190 (2000).

Stohs, M. and D. Mauer, “The Determinants of Corporate Debt Maturity Structure.” Journal of Business 69, 279-312 (1996).

Stulz, R., "Managerial Control of Voting Rights: Financing Policies and the Market for Corporate Control." Journal of Financial Economics 20, 25-54 (1988).

Subrahmanyam, V., N. Rangan and S. Rosenstein, "The Role of Outside Directors in Bank Acquisitions." Financial Management 26, 23-36 (1997).

Thomas, H., "Effects of Firm Ownership Structure on Hiring of M\&A Advisors." Journal of Financial Services Research 9, 159-175 (1995). 
Vafeas, N., "Board Meeting Frequency and Firm Performance." Journal of Financial Economics 53, $113-142$ (1999).

Woidtke, T., "Agents Watch Agents?: Evidence from Pension Fund Ownership and Firm Value." Journal of Financial Economics 63, 99-131 (2002).

Wruck, K., "Equity Ownership Concentration and Firm Value: Evidence from Private Equity Financings." Journal of Financial Economics 23, 3-28 (1989).

Yermack, D., "Higher Market Valuation of Companies with a Small Board of Directors." Journal of Financial Economics 40, 185-211 (1996). 